\title{
READERS
Insight
}

Journal of Management Info (JMI)

ISSN:2313-3376

www.readersinsight.net/jmi

$\sqrt{M A}$

\section{The impact of human resource management practices on employee retention a case of banking sector in Quetta Baluchistan}

\author{
Palwasha Kakara, Abdul Raziq ${ }^{\mathrm{b}}$, Faisal Khan ${ }^{\mathrm{c},{ }^{*}}$ \\ aMS Scholar, Sardar Bahadur Khan Women University Quetta, \\ ${ }^{b}$ PhD. Scholar, Faculty of Management, Universiti Teknologi Malaysia, Johor, Malaysia. \\ *Corresponding author: faisalkhanutm@yahoo.com
}

\begin{abstract}
The main objective of almost every organization is not only to select the right person for the right job but also to fascinate and retain them within the organization. Employee retention has considerable importance these days. This research was conducted to investigate how human resource management practices (employee compensation, employee training, appraisal system and employee empowerment) affect retention of banks employees. The data of this study was quantitative collected through questionnaire from 150 respondents from different banks of Quetta city. The results of the current study reveal that there is a significant positive relationship between human recourse management practices (empowerment, compensation, training and appraisal system) with employee retention. The study also discusses the limitations and recommendation for future research.
\end{abstract}

Keywords: Employee Empowerment; Compensation; Training and Development; Appraisal System; Employee Retention.

\section{ARTICLE INFORMATION}

\author{
Received: 25 March 2017 \\ Revised: 25 May 2017 \\ Accepted: 25 June 2017
}

DOI:

http://dx.doi.org//10.31580/jmi.v5i1.24

\section{Introduction}

Human resource is the most important asset of any organization as it is the source of achieving competitive advantage. In order to meet this challenge of achieving competitive edge the employers need to create such an environment that support the practices of retention. In which employees are encouraged. Once they are satisfied with their jobs, it will lead them towards commitment to their work as well as the organization and their intention to stay within the organization will be maximized.

Employee retention refers to the ability of the organization to retain its employees. It is the efforts by employers in maintaining such an environment that supports staff to remain within the organization for this purpose organization attempts to make policies that are aimed to meet the needs of the employees, enhance their job satisfaction, encourage and motivate them. Therefore the organizations want their employees to be more committed towards their work, performance and likely to retain in the organization. For any organization although hiring of competent employees is crucial, yet it is more important and challenging to retain those employees.

Narang (2013) stated that employee retention is a process in which organizations tries to retain their employees for longer period. The researcher further examined that for the retention purpose the policies and strategies are formulated in such a way to retain the workers in the organization. Retention is defined as "the ability to clutch onto those employees who are desired to stay, for longer period of time than those of the competitors" (Johnson, 2000). "Retention is an obligation to continue to do business or exchange with a particular company on an ongoing basis" (Zineldin, 2000). Stauss, et al., (2001) have defined retention as "customer liking, identification, commitment, trust, readiness to recommend, and repurchase intentions, with the first four being emotional-cognitive retention constructs, and the last two being behavioral intentions". Heathfield (2005) explained if an organization wants to gain long-term benefits and competitive advantage it retains its talented employees in the organization who can lead them to achieve the desired goals.

A motivational quote of Aristotle "pleasure in the job puts perfection in the work" one reason of the retention is the job satisfaction. It makes them more devoted and committed to their work; it results in organizational customer's satisfaction. For an effective and efficient performance of the firm, it is considered essential that firm retains its competent employees for longer period of time (Shekshnia, 1994). This researcher further argues that if an organization fails to do so, it cannot take advantage from its employees who are considered as an asset for the organization. Cloe (2000) has affirmed one of the reasons of employee retention that is if employees feel arrogance with company where they work this is source of motivation that is put in their efforts and they will try to give their best inputs. Freyermuth (2004) said human resource strategies play an important role in order to retain employees. The retention process starts when human resource management is applied that is right person for the right job. Employee retention is one of the most important targets for the organizations. Every organization attempts to introduce different human resource practices for this purpose. After review, the several articles relevant to employee retention the researcher selected the following four variables that affect employee retention. This study aims to describe how HR practices compensation, employee training, and appraisal system and employee empowerment influences employee retention in banking sector of Quetta city.

The importance of this study is to provide better approach to various human resource management practices those practices if implemented effectively, can reduce the turnover and maximize retention of the 
employees in banking sector. Bank is an institution that accepts deposits and lends those deposits whether directly or indirectly and it is considered a reliable industry of Pakistan like almost all other countries. But due to long working hours, stressful work in banks employees mostly prefer to work where they are given attractive compensations, they are being trained to enhance their skills which will create sense of being valued by the organization, better appraisal system as argued by Gomer-Mejia et al. (2004) for three factors of job those are "promotion", "rewarding" and "termination" performance appraisal can be used. In addition, empowering the employees in determining their work and involving them in decision-making. After gone through various articles and research papers related to employee retention, for this study following human resource practices are being selected those are employee compensation, employee training, appraisal system and employee empowerment.

\section{Literature review}

\section{Employee retention}

Chaminade (2007) cited in Fathi, Yazam and kamal (2011) retention is a "voluntary move by an organization to create an environment which engages employees for long term." Similarly, Kyndt and his colleagues (2009) defined employee retention, as it is a practice or method, which organizations attempt to retain its core employees. In the same way, Ahlrichs (2000) reported that retention is those policies and practices, which organizations implement in order to keep their core employees within the organization. For this purpose, organizations take different steps to make them stay for longer period. The researcher further argues although it is important to hire talented employees, yet to retain them is crucial for the organizations.

Employees are considered as an asset of the organization and their replacement is problematic. To retain the talented employees in the organization different measures are taken. The organizations, who fail to do so, may face adverse situation. (Meaghan stovel, nick bontis, 2002). Similar to the views of Meaghan other researchers have also stated the effects of turnover of the skilled employees, which are as 1 . The organization will remain with the problem of understaffing, 2. Less qualified employees and this will result in decreasing the competitiveness. (Rappaport, Bancroft, and Okum, 2003). Heathfield (2005) explained if an organization wants to gain long term benefits and competitive advantage, it retains its talented employees in the organization who can lead them to achieve the desired goals. Osteraker (1999) relates job satisfaction and job retention with the success of the organization. The researcher has categorized the retention in to three dimensions named as social, mental and physical. Mental dimension is related to the work characteristics. The priority of employees is towards that work they have the opportunity to use their knowledge and skills and get the feedback, which will lead to retention.

The social dimension is the associations of employees with other people. Physical dimension of retention is associated with working circumstance and pay. According to Panoch (2000), the talented and competent employees are problematic to be replicated, that is why organizations put their best efforts in order to retain these employees. From the literature it can be concluded that retention is the "relationship between employees and organization "where as turnover is defined as "any permanent departure beyond organizational Boundaries" (Cascio, 1995). Below the relationship between each of the human resource management practices with employee retention are discussed, which are the impact of employee compensation, employee training, performance appraisal and employee empowerment.

\section{Employee compensation}

Compensation is considered as the most important factor for employee retention. According to William (2007), companies formulate and implement the compensation policies in such a way that their employees are thrilled. The higher the employee satisfaction, the more they are dedicated to their work. Pay plays a vital role in employee retention. Milkovich and Newman (2004) have considered pay as a chief factor in retention. Lawler, (1990) viewed that the more competitive labor market is, the high wage strategy a company assumes. In addition, opposite to this company likely to implement the low wage strategy if comparatively trouble free and easy work is involved in low contending markets. William and Dreher, (1992) regard the compensation as essential means of employee attention as well as their retention. Gardner DG, van dyne L, Pierce. JL (2004) has concluded that compensation is the factor through which employees are willing to bestow their efforts, more devoted and likely to stay in the organization. The research conducted by Sanjeeve Kumar (2012) explored five factors that influence the retention of employees. The study revealed compensation is the most attractive factor, which can greatly affect the employee retention. Similar to these findings research carried out by Francis (2014) also showed compensation and benefits had very positive impact on employee retention. Compensation is both in the form of money and non-cash. In form of money, that employee receives in circumstances such as damage or harm, salaries or wages given by the employers to their employee or rewards. In form of non-cash, includes the benefits such as pensions, insurance (health or life), allowances, or retirement plans. (Hong, Lam, Kumar, Ramendran, Kadiresan, 2012).

Past studies also pointed that money is not only the factor for the retention of the employees. Smith, (2001) has argued that although money is source of attraction for the employees, yet not necessarily to retain them in the organization. Furthermore, Ashby and Pell regard money as source of satisfaction but the decision to stay in the organization is not totally dependent on compensation. Employee retention is based on the effective strategies formulated by the organization. They retain their employees even without paying high compensation (Pfeffer, 1998). According to Brannic (1999), principal factor for employee retention is not based on money. Highhouse, Stierwalt, Bachiochi, Elder and Fisher, (1999) has stated that through low compensation package employees are not attracted but at the same time there is no guarantee to retain them by offering high compensation. Not only pay is the factor for retention but also other factors such as work environment, co-workers support and supervisor support etc are the factors that are important in intention to stay within the organization. From the literature, it can be concluded that compensation is an important factor for employee retention as money can influence employees' behavior and ensure long-term employment.

\section{Employee Training}

Goldstein (1980) and Latham (1988) have defined training as "the systematic acquisition and development of knowledge, skills and attitudes required by employees to adequately perform an assigned job or task to boost performance in the job environment." The purpose of training can be achieved that is to convey new knowledge and skills if it is designed proficiently (Salas, 1999). Huselid (1995) has recommended that for employee retention the human resource practices such as training and job security play imperative role. Some other researchers especially, Lazear (1986); Madrian (1994); Gruber and Madrian (1994) have considered the human resource practices benefits and training as the motivator these practices "lock" the employees or retain them to the job. They stated that these practices are negatively related to turnover and have positive effect on employee retention. Ahmad and Bakar (2003) suggest that employees who recognize the benefits from training will tend to be more committed and so be more willing to participate in an organization's training activities.

Samganakkan (2010) acknowledged in his research the human resource practices such as training, appraisal system, and compensation as essential determinants of employee retention. These practices play important role in employee retention. The researcher has stated that organizations that desire to be successful they need to reduce turnover and make the compensation plan in such a way that positively affect the decision to stay. He regards training as an 
important determinant that motivates the employees and retains them in the organization. Training has positive relation with employee retention. It creates a sense of worth in employees. As through training organizations invest on their employees to enhance their knowledge and skills this leads to their career development. Messemer (2000) has stated that employees retention is dependent on the organization's decision to invest in employees training that will lead to their career development. Wetland (2003) has considered training as an essential factor in reducing turnover and increasing intention to stay. An organization that wants to obtain competitive advantage needs to get its employees trained in recent and updated technologies (Tomlinson, 2002). Many researchers have found that Training and development has significant relation with employee retention (Hong, Hao, Ramendran and Kadiresan, 2012; Asil, Akhlagh and Maafi 2013; Johri, Yahya and Ahmed 2012). Study by Tangthong, trimetsoontorn and Rojniruntikul (2014) examined human resource management practices (compensation and benefits, reward system and training and development) on employee retention with employee engagement as mediating variable. Study showed positive relationship with HR practices. However, in this study it was also concluded that training alone cannot increase employee retention but should be accompanied by other practices.

From the literature, it can be concluded that the concept of training is to provide skills and knowledge to employees for present task, on the other hand development based on skills and education of employees for present and future task. In addition, through the practice of training a sense of being valued can be created among the employees. Through training employees' skills and knowledge will be enhanced as technology is rapidly changing and organizations need to adopt the changes to be in the race of competition. If employees are given proper training as required, their knowledge and skill will not become obsolete.

\section{Performance appraisal}

According to Grote (2002) performance appraisals are a systematic way of evaluating the standard of a worker's performance." The researcher has viewed the two terms which are used interchangeably in research studies are named as "performance appraisal" and "performance evaluation." German and Saks (20011) delineate the performance appraisal as a process through which employees are evaluated in accordance to their job performance that smooth the progress of career development. The researchers further argued that performance appraisal scrutinizes the individual's general involvement to the organization and his/ her potential to attain higher position in the organization. For appraisal system parties, the evaluator and the respondents should realize its worth. If not so, it is observed that appraisal can be stressful for both the evaluator and the respondent. Webster, Beehr and Love (2011) in their study observed the effects of work stressors those are role vagueness and conflicts, dissatisfaction and turnover. Similar to the views of Webster, Beehr and Love (Year) other researchers have stated that stress has negative effect on employees' job performance. That is because employees give more significance to the appraisal system that will lead them to career development and compensation. (O'Connor, Arnold and Maurizio, 2010).

Performance appraisal plays an important role in attaining the desired goals as it motivates the employees and so that they will be more committed. (Ver Weire and Van Den Berghe, 2004). Sudin (2011) has given his views about the fairness in appraisal process that has effect on employee satisfaction, which results in positive relationship with organizational justice. Ghazali, Nysuki and Ishak (2011) studied, seven different human resource management practices like recruitment and selection, training, compensation system, performance appraisal, communication, employee empowerment and job security with employee intention to stay in hotel industry. Results of this study showed all these practices have significant relationship with employee retention however along with three other practices appraisal system was also found to be the most commonly practice carried out by KL hotel industry. Similar to these findings study carried by Rathanveera (2010) in Sri Lankan public sector banks. The results of this study showed significant relationship of other HR practices (compensation and benefits, training and development) performance appraisal and employee retention. From the past literature, it has been concluded that performance appraisal is mechanism through which employees' performance is being evaluated, the fairness of appraisal system can motivate the employees, their commitment to work, and intention to stay will be maximized.

\section{Employee empowerment}

According to the definition of the World Bank, "empowerment is providing individuals or groups with enough knowledge to allow them to make educated choices so that the result of those choices leads to responsible decision making. Hopefully these decisions will not only benefit the individual making them but also the organization or company, which allows the use of this empowerment." Employees are said to be empowered if they are given opportunity to participate in decision-making, goal settings and measures that are needed for motivation (Osborne, 2002). According to Kaye and Jordan- Evans (2001) the more empowered the employees are, the more they are committed to their work, that will lead to organizational success. Employees will likely be more committed and give their best efforts in performance as they are empowered in decision-making (Hummayoun Naeem and Muhammad Iqbal Saif, 2010).

According to Choong Wong and Lau (2011) employee is said to be empowered when there is sense of possession to retain in the organization. It also creates sense of belongingness among the employees they will likely to stay in the organization and ready to cope with the stress and challenges by others.

The study by Ongori (2009) after critically reviews of literature of employee empowerment it has been found that employee empowerment plays an important role in reducing turnover. Nedd (2006) cited in Ghazali, Nasyuki and Ishak (2011) employee empowerment is a mechanism through which employee retention is maximized. Moreover, it was also found in the study of ongori that empowerment creates a sense of worthiness among the employees that they can lead the organization towards the success, develops employee commitment towards organization, empowered employees contribute in organizational effectiveness, develop trust and encourages effective communication furthermore through the practice of empowerment workload of the top management is also minimized. From the literature it can be concluded like other human resource practices empowerment can also affect employee retention. When employees are empowered, they have the opportunity to determine their work; they are involved in decision making so they can make better use of their skills and knowledge, will be more committed to their work and organization and definitely will likely stay in the organization.

\section{Reasearch variables}

After literature, survey these variables were selected which are explained in the theoretical framework. These are employee retention is dependent variable and its relationship is to be checked with the independent variables, which are employee empowerment, employee compensation, Training and development and appraisal system.

\section{Hypothesis of the study}

H1: There is positive relationship between employee compensation and employee retention

H2: There is positive relationship between employee training and employee retention

H3: There is positive relationship between appraisal system and employee retention

H4: There is positive relationship between employee empowerment and employee retention 


\section{Research methodology}

Quantitative data was collected, using non-probability sampling technique. Questionnaires were distributed consist of 5- likert scale. The data was analyzed by using statistical package for social sciences (SPSS) version 16.0.

The secondary data was used by reading out the previous research articles and journals that helped in developing the theoretical framework whereas the primary data was gathered by using questionnaires. The questionnaires were got filled from the branches of Bank Alfalah, Allied bank and Dubai Islamic bank of Quetta city. In this research, the sample size was 150 and all the respondents provided feedback

The research instrument in this study is questionnaire. The aim reason for using the questionnaire is to get the direct feedback from the respondent that is less time consuming and can be achieve can be achieved in an unproblematic way.

\section{Data analysis}

After the data collection, the next step was towards data analysis. A co relational analysis was performed using the acquired data in order to check the relationships between the selected variables. For this purpose statistical package for social sciences (SPSS), 16.o was used. As this is very systematic computer program, which can deal with large amount of data and accuracy of results is assured. For this study, correlation and regression were analyzed.

\section{Theoritical framework}

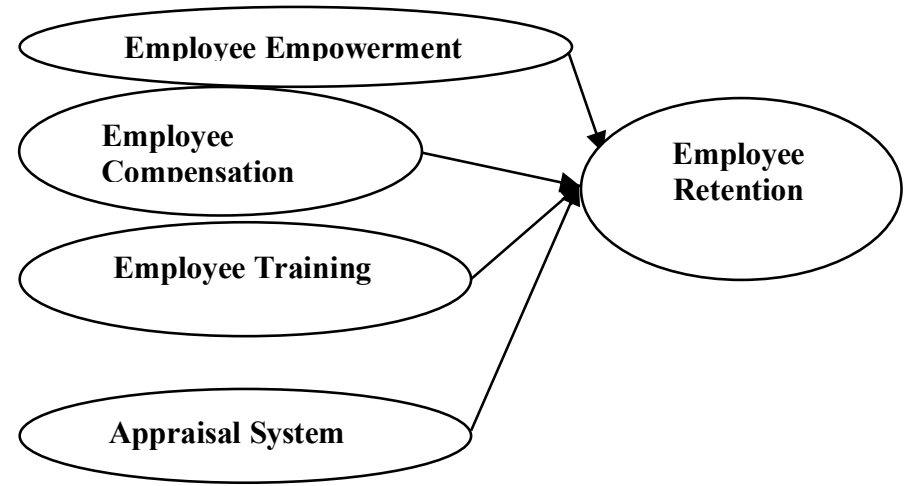

\section{Correlation and regression analysis of the research}

Correlation matrix shows the relationships between the dependant variable and independent variables those are employee empowerment, compensation, employee training and appraisal system. Results show that employee retention is dependent on these variables. This table shows that independent variables of the study (employee empowerment, employee training and compensation and appraisal system) have significantly correlated to retention. These variables have positive relation with employee retention.

\section{Regression Analysis}

According to model summary, the values of $\mathrm{R}$ show that these independent variables (employee empowerment, compensation training and appraisal system) contribute $2.17 \%$ towards dependant variable that is retention. It concludes $97 \%$ change in dependant variable due to other independent variables. The value of adjusted $\mathrm{R}$ square $1.16 \%$ represents the significant contribution of the independent variables toward dependant variable.

Table. 1: Correlations

\begin{tabular}{|c|c|c|c|c|c|c|}
\hline & & $\begin{array}{l}\text { empower } \\
\text { ment }\end{array}$ & \begin{tabular}{|l|} 
compensat \\
ion
\end{tabular} & $\begin{array}{l}\text { Trainin } \\
\mathrm{g}\end{array}$ & $\begin{array}{l}\text { apprais } \\
\text { al }\end{array}$ & $\begin{array}{l}\text { Retenti } \\
\text { on }\end{array}$ \\
\hline $\begin{array}{l}\text { Empower } \\
\text { ment }\end{array}$ & $\begin{array}{l}\text { Pearson } \\
\text { Correlation } \\
\text { Sig. (2-tailed) } \\
\mathrm{N}\end{array}$ & 150 & & & & \\
\hline $\begin{array}{l}\text { Compensa } \\
\text { tion }\end{array}$ & $\begin{array}{l}\text { Pearson } \\
\text { Correlation } \\
\text { Sig. (2-tailed) } \\
\mathrm{N}\end{array}$ & $\begin{array}{l}.544^{* *} \\
.000 \\
150\end{array}$ & $\begin{array}{l}1 \\
150\end{array}$ & & & \\
\hline Training & $\begin{array}{l}\text { Pearson } \\
\text { Correlation } \\
\text { Sig. (2-tailed) } \\
\mathrm{N}\end{array}$ & $\begin{array}{l}.521^{* *} \\
.000 \\
150\end{array}$ & $\begin{array}{l}.532^{*+} \\
.000 \\
150\end{array}$ & $\begin{array}{l}1 \\
150 \\
\end{array}$ & & \\
\hline Appraisal & $\begin{array}{l}\text { Pearson } \\
\text { Correlation } \\
\text { Sig. (2-tailed) } \\
\mathrm{N}\end{array}$ & $\begin{array}{l}.355^{* *} \\
.000 \\
150 \\
\end{array}$ & $\begin{array}{l}.503^{* *} \\
.000 \\
150\end{array}$ & $\begin{array}{l}.377^{* *} \\
.000 \\
150 \\
\end{array}$ & $\begin{array}{l}1 \\
150 \\
\end{array}$ & \\
\hline Retention & $\begin{array}{l}\text { Pearson } \\
\text { Correlation } \\
\text { Sig. (2-tailed) } \\
\mathrm{N}\end{array}$ & $\begin{array}{l}.476^{* *} \\
.000 \\
150\end{array}$ & $\begin{array}{l}.503^{* *} \\
.000 \\
150\end{array}$ & $\begin{array}{l}.387^{* *} \\
.000 \\
150 \\
\end{array}$ & $\begin{array}{l}.404^{* *} \\
.000 \\
150\end{array}$ & $\begin{array}{l}1 \\
150\end{array}$ \\
\hline
\end{tabular}

**. Correlation is significant at the 0.01 level (2tailed).

Table. 2: Model Summary

\begin{tabular}{|c|c|c|c|c|c|c|c|c|c|}
\hline \multirow{2}{*}{$\begin{array}{l}\text { Mo } \\
\text { del }\end{array}$} & \multirow[t]{2}{*}{$\mathrm{R}$} & \multirow{2}{*}{\begin{tabular}{|l|}
$\mathrm{R}$ \\
Square
\end{tabular}} & \multirow{2}{*}{$\begin{array}{l}\text { Adjuste } \\
\text { d R } \\
\text { Square }\end{array}$} & \multirow{2}{*}{$\begin{array}{l}\text { Std. Error } \\
\text { of the } \\
\text { Estimate }\end{array}$} & \multicolumn{5}{|c|}{ Change Statistics } \\
\hline & & & & & $\begin{array}{l}\mathrm{R} \\
\text { Square } \\
\text { Change }\end{array}$ & \begin{tabular}{|l} 
F \\
Change
\end{tabular} & df1 & df2 & \begin{tabular}{|l} 
Sig. F \\
Chang \\
e
\end{tabular} \\
\hline 1 & $.476^{\mathrm{a}}$ & & & 3.99865 & .227 & 43.343 & 1 & $\begin{array}{l}14 \\
8\end{array}$ & .000 \\
\hline 2 & $.558^{\mathrm{b}}$ & .311 & .302 & 3.78584 & .085 & 18.106 & 1 & $\begin{array}{l}14 \\
7\end{array}$ & .000 \\
\hline 3 & $.562^{c}$ & .316 & .302 & 3.78674 & .004 & .931 & 1 & $\begin{array}{l}14 \\
6\end{array}$ & .336 \\
\hline 4 & $.580^{\mathrm{d}}$ & .336 & .318 & 3.74335 & .020 & 4.404 & 1 & \begin{tabular}{|l|}
14 \\
5 \\
\end{tabular} & .038 \\
\hline
\end{tabular}

a. Predictors: (Constant), empowerment

b. Predictors: (Constant),

empowerment, compensation

c. Predictors: (Constant), empowerment, compensation, training

d. Predictors: (Constant), empowerment, compensation, training, appraisal

Table. 3: ANOVAe

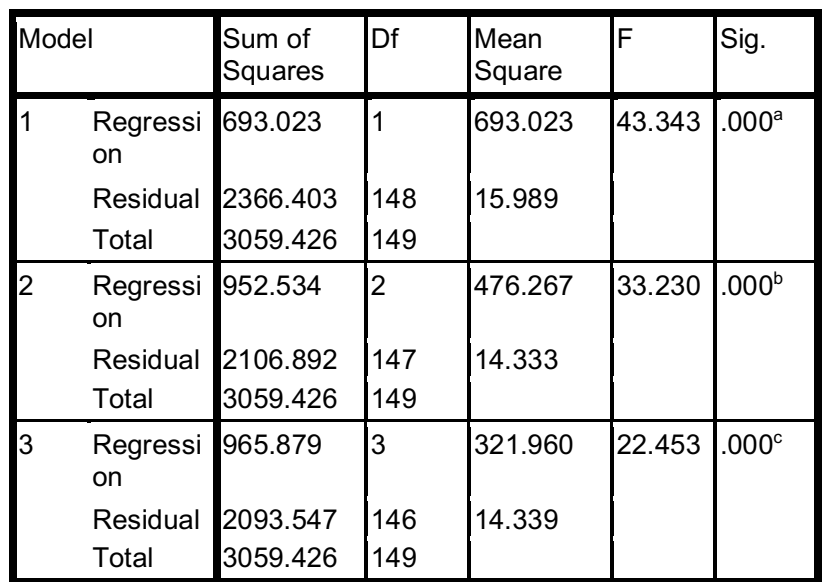




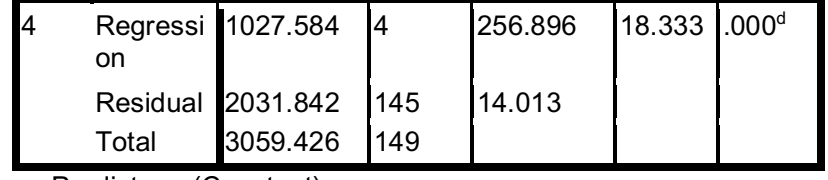

a. Predictors: (Constant),

empowerment

b. Predictors: (Constant), empowerment,

compensation

c. Predictors: (Constant), empowerment, compensation,

training

d. Predictors: (Constant), empowerment, compensation,

training, appraisal

e. Dependent Variable retention.

The ANOVA table shows satisfactory result, as the significance is not over than 0.05 . The model is significant.

Table. 4: Coefficients

\begin{tabular}{|c|c|c|c|c|c|c|c|c|c|c|c|c|c|}
\hline & \multicolumn{2}{|c|}{$\begin{array}{l}\text { Unstandardi } \\
\text { zed } \\
\text { Coefficients }\end{array}$} & \multirow{2}{*}{\begin{tabular}{|l|}
$\begin{array}{l}\text { Standar } \\
\text { dized } \\
\text { Coeffici } \\
\text { ents }\end{array}$ \\
Beta \\
\end{tabular}} & \multirow[t]{2}{*}{$\mathrm{T}$} & \multirow[t]{2}{*}{ Sig } & \multicolumn{2}{|c|}{$\begin{array}{l}95 \% \\
\text { Confide } \\
\text { nce } \\
\text { Interval } \\
\text { for B }\end{array}$} & \multicolumn{3}{|c|}{$\begin{array}{l}\text { Correlation } \\
\mathrm{s}\end{array}$} & \multicolumn{3}{|c|}{$\begin{array}{l}\text { Collinearity } \\
\text { Statistics }\end{array}$} \\
\hline & B & $\begin{array}{l}\text { Std } \\
\text { Err } \\
\text { or }\end{array}$ & & & & $\begin{array}{l}\text { Lo } \\
\text { wer } \\
\text { Bo } \\
\text { und }\end{array}$ & $\begin{array}{l}\text { Up } \\
\text { per } \\
\text { Bo } \\
\text { und }\end{array}$ & $\mid \begin{array}{l}\text { Zer } \\
\text { o- } \\
\text { ord } \\
\text { er }\end{array}$ & $\begin{array}{l}\text { Par } \\
\text { tial }\end{array}$ & $\begin{array}{l}\mathrm{P} \\
\text { art }\end{array}$ & $\begin{array}{l}\text { Toler } \\
\text { ance }\end{array}$ & VIF & \\
\hline \multirow[t]{2}{*}{1} & $\begin{array}{l}\text { (Consta } \\
\text { nt) }\end{array}$ & $\begin{array}{l}5.3 \\
99\end{array}$ & 1.514 & & $\begin{array}{l}3.5 \\
67\end{array}$ & $\begin{array}{l}.00 \\
0\end{array}$ & $\begin{array}{l}2.4 \\
08\end{array}$ & $\begin{array}{l}8.3 \\
91\end{array}$ & & & & & \\
\hline & $\begin{array}{l}\text { empowe } \\
\text { rment }\end{array}$ & $\begin{array}{l}.67 \\
9\end{array}$ & .103 & $\begin{array}{l}.4 \\
76\end{array}$ & $\begin{array}{l}6.5 \\
84\end{array}$ & $\begin{array}{l}.00 \\
0\end{array}$ & $\begin{array}{l}.47 \\
5\end{array}$ & $\begin{array}{l}.88 \\
2\end{array}$ & $\begin{array}{l}.47 \\
6\end{array}$ & $\begin{array}{l}.4 \\
76\end{array}$ & .476 & $\begin{array}{l}1.0 \\
00\end{array}$ & $\begin{array}{l}1.0 \\
00\end{array}$ \\
\hline \multirow[t]{3}{*}{2} & $\begin{array}{l}\text { (Consta } \\
\text { nt) }\end{array}$ & $\begin{array}{l}3.5 \\
50\end{array}$ & 1.498 & & $\begin{array}{l}2.3 \\
70\end{array}$ & $\begin{array}{l}.01 \\
9\end{array}$ & $\begin{array}{l}.59 \\
0\end{array}$ & \begin{tabular}{|l|}
6.5 \\
10
\end{tabular} & & & & & \\
\hline & $\begin{array}{l}\text { empowe } \\
\text { rment }\end{array}$ & $\begin{array}{l}.41 \\
0\end{array}$ & .116 & $\begin{array}{l}.2 \\
87\end{array}$ & $\begin{array}{l}3.5 \\
24\end{array}$ & $\begin{array}{l}.00 \\
1\end{array}$ & $\begin{array}{l}.18 \\
0\end{array}$ & $\begin{array}{l}.64 \\
0\end{array}$ & $\begin{array}{l}.47 \\
6\end{array}$ & $\begin{array}{l}.2 \\
79\end{array}$ & .241 & $\begin{array}{l}.70 \\
5\end{array}$ & $\begin{array}{l}1.4 \\
19\end{array}$ \\
\hline & $\begin{array}{l}\text { Compen } \\
\text { sation }\end{array}$ & $\begin{array}{l}.41 \\
1\end{array}$ & .097 & $\begin{array}{l}.3 \\
47\end{array}$ & $\begin{array}{l}4.2 \\
55\end{array}$ & $\begin{array}{l}.00 \\
0\end{array}$ & $\begin{array}{l}.22 \\
0\end{array}$ & $\begin{array}{l}.60 \\
2\end{array}$ & $\begin{array}{l}.50 \\
3\end{array}$ & $\begin{array}{l}3 \\
31\end{array}$ & .291 & $\begin{array}{l}.70 \\
5\end{array}$ & $\begin{array}{l}1.4 \\
19\end{array}$ \\
\hline \multirow[t]{4}{*}{3} & $\begin{array}{l}\text { (Consta } \\
\text { nt) }\end{array}$ & $\begin{array}{l}3.4 \\
68\end{array}$ & 1.501 & & $\begin{array}{l}2.3 \\
11\end{array}$ & $\begin{array}{l}.02 \\
2\end{array}$ & $\begin{array}{l}.50 \\
3\end{array}$ & $\begin{array}{l}6.4 \\
34\end{array}$ & & & & & \\
\hline & $\begin{array}{l}\text { empowe } \\
\text { rment }\end{array}$ & $\begin{array}{l}.37 \\
1\end{array}$ & .123 & $\begin{array}{l}.2 \\
60\end{array}$ & $\begin{array}{l}3.0 \\
16\end{array}$ & $\begin{array}{l}.00 \\
3\end{array}$ & $\begin{array}{l}.12 \\
8\end{array}$ & $\begin{array}{l}.61 \\
4\end{array}$ & $\begin{array}{l}.47 \\
6\end{array}$ & $\begin{array}{l}.2 \\
42\end{array}$ & .206 & $\begin{array}{l}.63 \\
0\end{array}$ & $\begin{array}{l}1.5 \\
88\end{array}$ \\
\hline & $\begin{array}{l}\text { Compen } \\
\text { sation }\end{array}$ & $\begin{array}{l}.37 \\
7\end{array}$ & .103 & $\begin{array}{c}.3 \\
18\end{array}$ & $\begin{array}{l}3.6 \\
53\end{array}$ & $\begin{array}{l}.00 \\
0\end{array}$ & $\begin{array}{l}.17 \\
3\end{array}$ & $\begin{array}{l}.58 \\
1\end{array}$ & $\begin{array}{l}.50 \\
3\end{array}$ & $\begin{array}{l}.2 \\
89\end{array}$ & .250 & $\begin{array}{l}.61 \\
9\end{array}$ & $\begin{array}{l}1.6 \\
15\end{array}$ \\
\hline & Training & $\begin{array}{l}.07 \\
7\end{array}$ & .080 & $\begin{array}{l}.0 \\
83\end{array}$ & $\begin{array}{l}.96 \\
5\end{array}$ & $\begin{array}{l}.33 \\
6\end{array}$ & $\begin{array}{l}- \\
.08 \\
1\end{array}$ & $\begin{array}{l}.23 \\
6\end{array}$ & $\begin{array}{l}.38 \\
7\end{array}$ & $\begin{array}{l}.0 \\
80\end{array}$ & .066 & $\begin{array}{l}.64 \\
0\end{array}$ & $\begin{array}{l}1.5 \\
61\end{array}$ \\
\hline \multirow[t]{5}{*}{4} & $\begin{array}{l}\text { (Consta } \\
\text { nt) }\end{array}$ & $\begin{array}{l}1.9 \\
77\end{array}$ & 1.645 & & $\begin{array}{l}1.2 \\
02\end{array}$ & $\begin{array}{l}.23 \\
1\end{array}$ & $\begin{array}{l}- \\
1.2 \\
74\end{array}$ & $\begin{array}{l}5.2 \\
28\end{array}$ & & & & & \\
\hline & $\begin{array}{l}\text { empowe } \\
\text { rment }\end{array}$ & $\begin{array}{l}.35 \\
4\end{array}$ & .122 & $\begin{array}{l}.2 \\
48\end{array}$ & $\begin{array}{l}2.9 \\
01\end{array}$ & $\begin{array}{l}.00 \\
4\end{array}$ & $\begin{array}{l}.11 \\
3\end{array}$ & $\begin{array}{l}.59 \\
5\end{array}$ & $\begin{array}{l}.47 \\
6\end{array}$ & $\begin{array}{l}.2 \\
34\end{array}$ & .196 & $\begin{array}{l}.62 \\
7\end{array}$ & $\begin{array}{l}1.5 \\
95\end{array}$ \\
\hline & $\begin{array}{l}\text { Compen } \\
\text { sation }\end{array}$ & $\begin{array}{l}.29 \\
9\end{array}$ & .108 & $\begin{array}{l}.2 \\
52\end{array}$ & $\begin{array}{l}2.7 \\
54\end{array}$ & $\begin{array}{l}.00 \\
7\end{array}$ & $\begin{array}{l}.08 \\
4\end{array}$ & $\begin{array}{l}.51 \\
3\end{array}$ & $\begin{array}{l}.50 \\
3\end{array}$ & $\begin{array}{l}.2 \\
23\end{array}$ & .186 & $\begin{array}{l}.54 \\
7\end{array}$ & $\begin{array}{l}1.8 \\
29\end{array}$ \\
\hline & Training & $\begin{array}{l}.05 \\
7\end{array}$ & .080 & $\begin{array}{l}.0 \\
61\end{array}$ & .71 & $\begin{array}{l}.47 \\
4\end{array}$ & -10 & $\begin{array}{l}.21 \\
5\end{array}$ & $\begin{array}{l}.38 \\
7\end{array}$ & $\begin{array}{l}.0 \\
59\end{array}$ & .049 & $\begin{array}{l}.63 \\
1\end{array}$ & $\begin{array}{l}1.5 \\
84\end{array}$ \\
\hline & $\begin{array}{l}\text { Apprais } \\
\text { al }\end{array}$ & $\begin{array}{l}.20 \\
7\end{array}$ & .099 & $\begin{array}{l}.1 \\
67\end{array}$ & $\begin{array}{l}2.0 \\
98\end{array}$ & $\begin{array}{l}.03 \\
8\end{array}$ & $\begin{array}{l}.01 \\
2\end{array}$ & $\begin{array}{l}.40 \\
2\end{array}$ & $\begin{array}{l}.40 \\
4\end{array}$ & $\begin{array}{l}.1 \\
72 \\
\end{array}$ & .142 & .72 & $\begin{array}{l}1.3 \\
75\end{array}$ \\
\hline
\end{tabular}

Table 4 shows that $1 \%$ increase in employee empowerment results increase in Dependant variable that is retention by $0.354 \%$, further shows that $1 \%$ increase in compensation leads increase by $0.299 \%$ in retention. The $1 \%$ increase in training leads increase in retention by .057 and increase $1 \%$ in appraisal leads .207\% increase in Dependant variable. The standardized Beta is used for Regression line to check the impact of every variable on dependent variable and un standardized Beta checks the overall results of independent variables on dependant variable. The highest beta shows the independent variable is the most significant variable towards dependant variable. From the above table it shows that the independent variable employee empowerment has the highest positive beta of 122 it means the variable employee empowerment has stronger effect on retention as compare to others.

\section{Discussion}

H1: There is positive relationship between employee empowerment and employee retention

From the hypothesis testing, the results show there is positive relationship between employee empowerment and employee retention. The value .476 indicates that employee empowerment is positively correlated to retention. Which shows correlation is significant up to 0.01 levels. Hence, hypothesis 1 is accepted. It is presumed that if employees are empowered by letting them contribute in the process of decision making, to cope with the changes and to determine their own job, it would definitely boost up the level of employee retention.(Tajammal Hussain and sana ur Rehman,2013)

H2: There is positive relationship between employee compensation and employee retention

From the hypothesis testing, it shows that there exists positive relationship between employee compensation and employee retention. The value .503 shows that compensation is positively related to employee retention. Correlation is significant up to 0.01 level. Hence Hypothesis 2 is supported. Compensation is considered as a key factor that has direct effect on the level of retention. The factor increases, so that they will likely to stay in the organization. Compensation motivates the employees it tends to improve their performance and they are likely to retain in the organization. This is consistent with the research done by (Eric Ng Chee Hong, Lam, Ramesh Kumar, Charles Ramendran, Vimala Kadiresan, 2012), where they found the significant relationship between employee compensation and employees' retention.

\section{H3: There is positive relationship between employee training and employee retention}

From the hypothesis testing, it shows that there is positive relationship between employee training and employee retention. The value .387 indicates that training is positively correlated with employee retention, which shows that correlation is significant up to 0.01 level. Hence, hypothesis 3 is accepted. Job related training is beneficial in many ways. As Thomas Acton and Wilie Golden in 2002 has stated that training enables the employees to solve the problems, increases confidence, motivate them which in return makes them more committed towards their work that will lead to reduction in turnover. Training programs are important for the development of the employees and as well as to retain them. The study in Malaysian higher education institutions by Hong et al (2012) "the impact of human resource management practices on employee retention" showed positive relationship between training and employee retention and considered important factor in retaining employees.

H4: There is positive relationship between appraisal system and employee retention

From the hypothesis testing, it shows that there exists positive relationship between appraisal system and employee retention. The value .404 shows that appraisal system is positively correlated with employee retention. Correlation is significant up to 0.01 levels. Hence Hypothesis 4 is supported. It is observed that when appraisal system is applied in an organization its objective is to examine the performance of the employees so that employees recognize their 
strengths and weaknesses. They are satisfied that they will be rewarded for their best performance. This is also advisable that appraisal system should be fair. It is an important factor to retain the core employees in the organization. This system clearly indicates the duties and responsibilities of the employees and leads them to career development. Justice, equity and fairness in appraisal system will be beneficial for the organizational commitment. (A.K. Paul and R.N. Anantharaman 2003).

\section{Conclusion}

Employees are valuable assets of any organization. In this ever changing, dynamic, and competitive environment, every organization tends to retain their employees for the successful accomplishment of organizational goals. Organizations have to provide their employees attractive compensation, training opportunities to learn new techniques to boost up their skills, fair appraisal system to identify their strength and weaknesses and to encourage them to give their best to the organization and empowerment to retain them in the organization.

Overall I have attempted in this study is to investigate how human resource management practices (compensation, training and development, appraisal system, employee empowerment) affects on employee retention in banking sector of Quetta city. The results of this research showed that positive relation exists between human resource management practices and employee retention. It can be concluded that the organizations who effectively and efficiently apply these HRM practices will likely to retain their core and high talented employees in the organization and human resource management practices have positive effect on employee retention.

\section{Limitations and recommendations of the study}

In this study the researcher, encounter some limitations. Firstly, time constraint was one the problems within limited time the researcher had to complete the study. Secondly, the study was cross sectional and the sample size for this study was limited. Thirdly, the respondents tend to be biased in answering the questionnaire provided to them. Forth the researcher only focused on the direct relationship among the study variables.

From the above-motioned limitations, the researcher recommends to include other outcome variables like organizational, turnover intention etc and there are many other HR practices which can influence employee retention, should be included in research. The researcher further recommends longitudinal and qualitative study as in qualitative study same unknown factors will also be explored and in qualitative study the respondents will not likely tend to be biased as compare to quantitative. The more correct data will be gathered if sample size is large enough and results that are more reliable will be obtained.

\section{References}

Ahlirichs, N.S. (2000). Competing for talent, key recruiting and retention strategies for becoming an employer choice. Palo Alto, CA: Davies Black Publishing.

ALDamoe, F. M. A., Sharif, M. Y., and Ab Hamid, K. (2013). The Causal Relationship between HRM Practices, Affective Commitment, Employee Retention and Organizational Performance. International Business Management, 7(3), 191-197.

Asil, S. M. N, Akhlagh, E. M and Maafi. S. (2013). Analyzing the relationship between human resource management activities and employees' intention to stay in the organization through organizational commitment. International journal of Agriculture and crop sciences.

Brannnick, Joan. ('1999). Employees; job satisfaction; labor turnover; recruiting, AMACOM (New York)

Cassico, W., F, (1995). 'Managing human resource' international edition, US: McGraw Hill
Cole, C.L (2000). Building loyalty workforce. 79, 42-49. Available EBSCOhost fully display

Davies, D., Taylor, R, Savery, C. (2001). The role of appraisal, recruitment and training in improving staff relation in western American accommodation industry. A comprehensive study journal of European training, 25(6/7). 366-373

Denton, J. (2000). Using web-based projects in a system design and development course. Journal of computer information system, vol.40 no 3 , pp $85-7$

Eric.Ng C.H, Lam,Z. H, Charles ,R and vimala ,K. (2012). An effectiveness of human resource management practices on employee retention in institution of higher learning: A regression analysis. International journal of business research and management. (IJBRM), volume (3): issue (2)

Francis, A. U. (2014). Human resource management practices and employee retention in Nigeria's manufacturing industries. International journal of scientific and engineering research, 5(2).

Ghazali, H., Nasyuki, N. M., Yi, O. X., and Ishak, M. B. (2011). Human Resource Practices and Employees ${ }^{\text {ee }}$ intention to stay in the Kuala Lumpur hotel industry.

Gardner, DG, Van Dyne, L., pierce, JL. (200). the effect pay level on organization-based self esteem and performance: a field study. Journal of occup.organ psychology, 77(3):307-322

Graber, J., and Madrian, B.C. (1994). Health insurance and job security: the effect of public policy on job-lock. Industrial and labor relation review, 48(1), 86-102

Grote, R.C., 2002. The Performance Appraisal Question and Answer Book: A Survival Quide for Managers. American Management Association, New York.

Gurman and saks (2011). Performance management and employee engagement. Human Resource Management Review 21(2011) 123136

Heathfield, M. (2005). Effects of pre interview belief on applicant's reaction to campus interviews. Academy of management journal, 40(4), 947-966

Highhouse, S., StierWalt, S.L., Bachioci.P, Elder, A.E and fisher, G. (1999). Effects of advertised Human Resource Management practices on attraction of African American applicants in personnel psychology. 52(2): 425-26

Hong, E. N. C., Hao, L. Z., Kumar, R., Ramedran, C., and Kadiresan, V. (2012). An effectiveness of human resource management practices on employee retention in institute of higher learning: A regression analysis. International Journal of Business Research and Management, 3(2), 60-79.

Huselid, M.A. (1995). The impact of Human Resource Management practices on turnover, productivity and corporate financial performance. Academy of management journal, 38(3): $\quad$ 635-672

Hummayoun Naeem and Muhammad iqbal saif. (2010). Employees empowerment and customer satisfaction: empirical evidence from the banking sector of Pakistan. African journal of business management. Vol.4 (10), pp. 2028-2031

Huselid, M. A., Beatty, R. W., and Becker, B. E. 2005. “A player" or "A positions?" The

Strategic logic of workforce management. Harvard Business Review, December: 110-117

Johari. J, Yahya, K. K and Ahmed, M. N (2012). Understanding the influence of human resource management practices on intention to stay: evidence from Malaysia. $3^{\text {rd }}$ international conference on business and economic research.

Johnson, M. (2000). Winning the people war, talent and battle for human capital, copyright licensing Agency, London

Kaye, B., and Jordon-Evans. S. (2001). Retaining key employees. Public management, 1, 6-11

Lawler, Edward, E. (1990). Compensation management; strategic planning; pay-for knowledge system, Jossey- bass publishers (San Francisco)

Lezean, E.P. (1986). Retirement from the labor force. In Ashenfelter, O., and Layard, R. (Eds). Handbook of labor economics, vol 1. Amsterdam: north- Holland

Madirian, B.C. (1994). Employment-based health insurance and job mobility: Is there evidence of job-lock? Quarterly journal of economics. 109, (February)

Malhotra, N.K. (2007). Marketing Research: An applied orientation (5th ed.). New Jersey: prentice H1l

Meaghan Stevel, Nick Bontis. (2003). Voluntary turnover: knowledge management-friend and foe? J. intellect. Cap. 3(3): 303-322

Messmer, M. (2000). Orientation programs can be key to employee relation. In strategic finance. 81(8): 12-15

Milkovich, GM, newman, JM. (2004). Compensation ( $8^{\text {th }}$ ed). Burr Ridge, IL: Irwin McGrraw-hill 
Ongori, H. (2009). Managing behind the scenes: A review point on employee empowerment. African journal of business management. 3(1), 009 015 .

Paul, A.K and Anantharaman, R.N., (2003). Impact of people management practices on

organizational performance: analysis of a causal model , Int. J. of Human Resource

Management 1246-1266

Peterson, C., Park, N. and Seligman, M.E.P. (2006). Greater strengths of character and

recovery from illness. The Journal of Positive Psychology, 1(1), 17-26

Pfeffere, J. (1998). Six myths about pay. Havard Business Review, may- June, $38-57$

Ponch, A. (2001 May). The relationship between diversity and employee relation. Master's thesis, university of Wisconsin- south, Menomonie

Rappaport, A., Bancraft, E., and L. (2003). The aging workforce arises new talent management issues for employees. Journal of organizational excellence, 23, 55-56

Rathnaweera, R. R. N. T. (2010). Do HRM practices impact employee satisfaction, commitment or retention? :( Empirical studies of Sri Lankan public sector banks)

Smith, M.K. (2001). 'Young people, informal education and association', the informal homepage, www. Infed.org/ youth work/ YPandassoc. Html. Latest updates: December 2001

Stuauss, B., Chojnachi, K, Decker, A, Hoffman, F. (2001). Retention effects of a customer club. International journal of service industry management, vol 12 no. 1 , pp.7-19

Sudin (2011). Fairness of and Satisfaction with Performance Appraisal Process Journal of

Global Management July 2011. Volume 2, Number 1.Webster, Beehr and Love (2011)

Extending the of Vocational Behavior $\mathrm{xxx}$ (2011) $\mathrm{xxx}-\mathrm{xxx}$.
Tajammal, H, Sheikh, S. R. (2013). Do HRM practices inspire employee retention? Research Journal of Applied Sciences, Engineering and Technology 6(19): 3625-3633ISSN: 2040- 7459; e-ISSN: 2040-7467 Maxwell Scientific Organization, 2013

Tangthong, S., Trimetsoontorn, J., and Rojniruntikul, N. (2014). HRM Practices and Employee Retention in Thailand--A Literature Review. International Journal of Trade, Economics and Finance, 5(2).

Thomas Acton and Willie Golden. (2002, June). Training: The way to retain valuable IT employees. Retrieved March 28, 2012, from Informing Science.

Tomlinson, A. (2002). High technology workers want respect. Survey Canadian Human Resource Report, vol. 15, issue 3, and p.2

Uma narang. (2013). HRM practices- its impact on employee retention. International journal of multidisciplinary

Verwier, K, and Van Den Berghe, L. (2004). Integrated performance management: New hyper or new paradigm? In k. verweir and L. Van Den Berghe (eds). Integrated performance management. (pp.1-14). thousand oask, CA: sage publications

William, M., and Dreher, G. (1992). Compensation system attributes and applicant pool characteristics. In academy of management journal. 435:571-95

Willis, C. (2000). Go for your goals. Working woman. Pp, 6-7

Zineldin, M. (2000). TRM total relationship management, student literature, Lund 